\title{
A pragmatic reversal: Italian per favore 'please' and its variants between politeness and impoliteness
}

\author{
Chiara Fedriani \\ University of Genoa
}

\section{ABSTRACT}

This paper examines a range of impolite values recently developed by the Italian politeness markers per favore, per piacere, and per cortesia 'please' in conflictive contexts. In describing this functional development, I adopt Mazzon's (2017) definition of 'pragmatic reversal', i.e., a shift whereby a politeness marker is progressively used with confrontational meanings. Drawing on a corpus of online written Italian, this study analyzes the interactional contexts where politeness markers are used impolitely and suggests an explanatory path for their reversal. The corpus-based study shows that typical contexts of confrontational uses are impolite commands, prohibitions, and quotative constructions reporting a content which is harshly criticized and challenged by the writer. In the latter case, the politeness markers (usually prefaced by $m a$ 'but') function as extra-clausal markers of disagreement - some also occurring as holophrastic interventions to rebut the interlocutor's argument.

The idea developed in this paper is that politeness formulae are prone to pragmatic bleaching precisely in view of their routinization as 'politic', conventional, and neutral forms. Once partially bleached, they start acquiring new values within the realm of modulation, even - and this is the interesting fact - in the 'opposite' direction, as insistent reinforcement of impolite acts such as urgent pleas, rude requests, rebuttals, and even insults. This pathway of impoliteness-driven pragmatic change has also been documented for some English markers such as please, sorry and I'm afraid, which suggests the emergence of a recurrent pattern of pragmatic reversal involving equifunctional forms in different languages.

Key-words: politeness markers, impoliteness, pragmatic reversal, directives, Italian

\section{Introduction}

Per favore 'please' (lit. 'for favour') is the most common politeness marker (henceforth, PM) in Contemporary Italian, alternating with two less frequent variants, per piacere and per cortesia. In their typical uses, these PMs mitigate orders and requests (ex. 1), also in the form of exhortations in the $1^{\text {st }}$-person plural (ex. 2), and often containing a modal verb (ex. 3).

(1) Ragazze sedetevi per favore (LIP corpus) 'Girls sit down please'

(2) Smettiamola con queste cose per favore (Paisà corpus) 'Let's just drop the whole business please' 
(3) Buonasera potrei parlare con Gianluigi per favore* (LIP corpus)

'Good evening can I speak with Gianluigi please?'

Interestingly, however, in some colloquial registers all three PMs have recently developed a range of impolite values in conflictive contexts, where they exacerbate, instead of mitigating, the urgency of the request. Impolite uses are found above all in two specific interactional contexts. The first is constituted by rude directives, often in the form of prohibitions (ex. 4) and even of conventionalized insults (ex. 5-6). These passages are drawn from a corpus of online written Italian that gathers together a variety of web pages such as blogs and forum chats (Corpus Paisà: see Section 3). The impolite connotation of the context is also evinced by the use of curse words, which are graphically concealed in (5) and (6).

(4) Non scrivete stronzate per favore!

'Don't write bullshit please!'

(5) "il mio ex S4RS gli da una pista...quella si che è LA REGINA DELLE NAKED!!!!!” Ma vai a cag... per favore se quel bidone prendeva badilate già dalla $910 ! ! ! !$

، “my ex S4RS is much better...now that's THE QUEEN OF NAKED!!!!!” But

fuck... please that piece of junk took already hits from the 910 !!!!!'

(6) se volete menatevi quanto volete, anzi decimatevi pure da soli, ma fuori dai coxxxxi per cortesia

'if you want to fight do so, even annihilate yourselves, but get the fxxk out of here please'

In the second context, impolite per favore/piacere/cortesia occur outside the clause and function as markers of disagreement or emotionally loaded rebuttals of the interlocutor's point of view. In such cases, these markers are grammatically isolated and added as afterthoughts. The typical construction features a quotation of the argument to be challenged, which is often reported with a sarcastic and critical connotation, followed by an extrastructural per favore/piacere/cortesia which counters its validity. An example of this pattern is given in (7), where per favore (prefaced by ma 'but': we will come back to this in Section 4) expresses indignation and disagreement with those who 'get angry if the Italian goalkeeper Buffon concedes a goal'. Likewise, in (8) a suspended per piacere closes a rude recrimination by signalling dissent. Quotations of the interlocutor's ideas are imbued with sarcasm and verbal aggression, conveyed in (7) by the expression avere il coraggio di 'to dare to' and in (8) non sai di cosa stai parlando 'you don't know what you're talking about': 
(7) e poi magari abbiamo anche il coraggio di prendercela con Buffon se prende goal ... ma per favore!!!!!

'and then perhaps we also have the courage to get angry with Buffon if he concedes a goal... but please!!!!’

(8) Ovviamente non sai di cosa stai parlando ... Fisica ... Grafica ... per piacere 'Of course you don't know what you're talking about... Physics... Graphics... please'

Expressions like those given in (4) to (8) can be interpreted as cases of mixed messages, "which mix features which point towards a polite interpretation and features which point towards an impolite interpretation" (Culpeper 2011: 165-166). The link with conventionalization becomes however a lot more tangible in the case of what Culpeper calls verbal formula mismatches, such as I hate to be rude but and no offence but, since "they express some mitigation of the negative impact of what is just about to be delivered" without preventing the speaker, however, to deliver it (Culpeper 2011: 174-178). Such expressions originally convey conventional politeness but, as Culpeper shows, they often give rise to conventionalized impolite mixed messages - that is, these are mixed messages conventionalized as impolite. I will show that $(\mathrm{ma})$ per favore/piacere/cortesia are used with a confrontational meaning along similar lines and that, at least in some registers and conversational contexts, a new impolite pattern has recently been conventionalized.

In order to account for this pragmatic development, I incorporate the notion of mixed message within a more systematic process of functional expansion called 'pragmatic reversal' (Mazzon 2017), i.e., a pragmatic shift whereby a politeness marker is progressively used with conflictive meanings. This means that the original value and the new function developed by the markers involved are symmetrically opposite, i.e., reversed. Mazzon (2017: 280) was the first to speak of a 'reversal' in relation to a shift undergone by English I'm afraid and well, and showed that these markers, which seemed to be used "to reduce friction and conflict tend to be used later to even increase confrontation [...] their functions shift from the expression of a hedging or apologetic stance to that of a challenging and confrontational one". A case in point provided by Mazzon (2017: 297) is (9), where I am afraid has scope over an order and strengthens its illocutionary force.

(9) 'I'm afraid I must ask you to leave,' I said. (Bette Howell, Dandelion Days. 1991, $\mathrm{BNC})$ 
Now, it is important to note that a strategic context for the reversal of (ma) per favore/piacere/cortesia is when impolite orders are modified by a 'mock' PM. If we consider example (10), for instance, it is clear that per favore actually disguises an impolite attitude while modifying the rude directive accendi il cervello 'switch your brain on'. Ambiguous messages of this type presumably constituted bridging contexts leading to a form-function pragmatic reanalysis.

(10) Quindi per favore accendi il cervello prima di parlare.

'So please switch your brain on before talking'

More crucially, Mazzon (2017) suggests that the reversal undergone by the English PMs she discusses is to be classified as "deontic", because the pragmatic switch is mostly found in contexts in which the speaker contradicts the interlocutor, often in terms of prohibition or refusal. Interestingly, as we will see, the data scrutinized in this paper support a pathway of change along similar lines: the reversal of per favore/piacere/cortesia took place in the realm of directives, starting from polite requests softened by 'true' PMs and ending up in orders and prohibitions where (originally) polite modifiers function as upgraders, rather than downgraders, of illocutionary force.

Needless to say, the context of interaction plays a substantial role in the perceived connotation of the downgrader vs. upgrader function of a PM. Leech (2014: 162) cites the case of nonsentential requests such as Tickets please, or answers to offers like Yes, please, where please is indispensable as a marker of routine politeness. By contrast, when please is characterized by an emphatic intonation, it functions rather as an "insistent reinforcement of the directive", as in (11):

(11) Richard! Stop driving please! Please Richard! Please Richard! Please stop jumping on the chair arms will you? (BNC KB8, from Leech 2014: 162)

Wichmann (2005) has neatly shown in this regard that when please conveys urgency it usually carries a high pitch accent, with a parallel de-accenting of the adjacent request. She further explains that many models associate accentual prominence with information status, whereby an emphatic accent status correlates with 'new' information: in such cases, "the actual [...] request is treated as given, and the courtesy marker becomes the 'new' information. The implied proposition is now 'I urge you to do it' rather than 'I permit it"' (2005: 243). 
Building on these premises, this paper further explores a pragmatic change in which formulae pertaining to the 'politic' language of mitigation (in the sense of Watts 1992) are progressively routinized as part of a respectful, affectively neutral code. The idea developed in this study is that such formulae are prone to pragmatic bleaching precisely in view of their crystallized routinization. Once partially bleached, they can start acquiring new values within the realm of modulation, even - and this is the interesting fact - in the 'opposite' direction, straying far from the original semantic core of politeness, towards reinforcement of impolite acts. As mentioned above, this seems to be a recurrent pathway of pragmatic change: besides the cases commented on by Mazzon (2017), evidence comes from certain impolite uses of please (Wichmann, 2005; Barron, 2008: 50-51; Aijmer, 2015), and from some challenging values developed by I'm sorry (Murphy, 2015). To my knowledge, no work has been done on this aspect of Italian politeness markers, and this paper aims to fill this gap.

The remainder of the article is organized as follows. Before turning to the pragmatic reversal recently undergone by Italian PMs in Section 4, in Section 2 I briefly sketch out their historical development. Section 3 presents the data and the methodology adopted. Section 5 concludes the paper with a summary of the analysis developed.

\section{Background: the history of per favore}

Research on politeness strategies in Italian is quite a recent field. Held $(2005,2010)$ provides the first systematic attempts to characterize this functional domain and shows that in Italian there is a tendency towards positive politeness strategies. They include deictic distance softeners (e.g., the polite imperfetto, the subjunctive and the conditional: Held, 2005: 302), downtoners (forse 'maybe', un po' 'a bit', per caso 'by chance') and diminutives (Dressler and Merlini Barbaresi, 1994: 228-263), modesty formulas and deferential address forms (Scaglia, 2003). Little research, however, has been carried out on the diachronic development of Italian politeness markers, exceptions being Ghezzi (2015) on thanking formulae, Ghezzi and Molinelli (2014) on request modifiers from Latin to Italian, and Molinelli (forthc.) on address forms. Bazzanella's (2003) paper constitutes the only work on Old Italian and looks at evidential parentheticals and forms of address. To my knowledge, however, there is no work on Italian politeness request formulae, and a diachronic analysis on their pragmaticalization is likewise still lacking. 
Quite surprisingly, the conventionalization of per favore as a PM in Italian is a recent fact. In Old Italian, typical strategies to soften directives included verbal periphrasis expressing impositive requests, featuring the verb piacere 'to like' and the use of performative locutions, like chiedere mercede che 'mercifully ask that' (ex. 12) and pregare che 'to pray that' (ex. 13). Note, however, that all these forms were never used parenthetically in Old Italian (Bazzanella, 2003: 252; see further Held 2010: 209-210).

(12) io vi cheggio mercede che voi la diate a uno più ricco omo ch'io non sono (Novellino, 49, 25-26; from Renzi 2010 II: 1209)

'I mercifully ask that you give her to a man richer than myself'

(13) vi priego per quello amore e per quella amistà la quale è tra noi, che di me vi ricordi (Boccaccio, Decameron X, 9; from Ghezzi and Molinelli 2014: 79)

'I beg you, in the name of love and friendship between us, that you remember me'

From the $16^{\text {th }}$ to the $18^{\text {th }}$ centuries a fixed inventory of deferential strategies, titles, and courtesy forms gradually emerged and progressively expanded, giving rise to a complex inventory that informed interpersonal communications and rituals with a systematic 'social tact' (Held, 2005: 295). The terms grazia 'grace', piacere and favore 'favour', cortesia 'courtesy' and carità 'love' all became key notions in the $18^{\text {th }}$-century Italian politeness system and gave rise to frozen requesting formulae such as fare un piacere/grazia 'do a favour/an act of grace', prego per cortesia 'I pray for courtesy', ditemi in grazia 'tell me in grace' (Held, 2005: 298-299). Examples (14) and (15) show some of these formulae:

(14) Orsú, fatemi il piacere, andate via di qua [...] Per carità, andate via. (Goldoni, La famiglia dell'antiquario I, 5)

'Come on, do me the favour of getting away from here [...] Please, get away'

(15) Fatemi grazia almeno di dirmi, in cortesia, giacché tanto mi onora, chi è vossignoria? (Goldoni, Torquato Tasso II, 10)

'At least do me the grace to say to me, in courtesy, since you honor me so much, who is your Lordship?'

In order to get a more detailed picture of the diachronic development of such politeness formulae, I scrutinized the occurrences of verbal locutions and Prepositional Phrases occurring as polite modifiers of requests at regular intervals of approximately 200 years, in a selection of plays drawn from the Biblioteca Italiana repository of digitized documents for 
the 16th and 18th centuries and from the Liberliber archive for the 20th century (Table 1). ${ }^{1}$

\begin{tabular}{|c|c|c|c|c|c|c|c|c|}
\hline & \multicolumn{4}{|c|}{ PREPOSITIONAL PHRASES } & \multicolumn{3}{c|}{ VERBAL LOCUTIONS } \\
AS POLITE MODIFIERS & \multicolumn{2}{c|}{$\begin{array}{c}\text { per } \\
\text { in/per } \\
\text { cortesia }\end{array}$} & $\begin{array}{c}\text { per } \\
\text { carità }\end{array}$ & $\begin{array}{c}\text { per } \\
\text { favore }\end{array}$ & $\begin{array}{c}\text { per } \\
\text { piacere }\end{array}$ & $\begin{array}{c}\text { farer } \\
\text { grazia }\end{array}$ & $\begin{array}{c}\text { fare un } \\
\text { piacere }\end{array}$ & $\begin{array}{c}\text { fare un } \\
\text { favore }\end{array}$ \\
\hline 1500 & 92 & 5 & & & & 4 & 3 & \\
\hline 1700 & 22 & 5 & 31 & 3 & & 5 & 22 & \\
\hline 1900 & & & & 10 & 8 & 5 & 24 & 5 \\
\hline
\end{tabular}

Table 1. Politeness strategies in sub-corpora of Italian plays

The data show that in the $16^{\text {th }}$ century there was a clear preference for expressions built upon the term grazia, whose frequency decreased in the $18^{\text {th }}$ century, a period where we find a wider range of variation, with the expressions per carità and fare un piacere as the most frequently used. In the $20^{\text {th }}$ century, in/di/per grazia was no longer attested and was replaced by the emergent formulae per favore and per piacere.

Crucially, the three occurrences of per favore in the $18^{\text {th }}$-century sub-corpus still work as Prepositional Phrases with scope over the verb. This is evident in (16) featuring the verb chiedere 'to ask': the addition of per favore specifies that the request is made 'in terms of a favour', and in (17), where a Countess asks her interlocutor to shut up, 'at least as a favour'.

(16) In grazia mia restate, vel chiedo per favore; a dama che vi prega, risponderete un no? (Goldoni, Torquato Tasso III, 3)

'For my grace do remain, I ask you as an act of favour; to a lady who praises you, will you say no?'

(17) Potrebbe un po' star zitto, almeno per favore? (Goldoni, La donna bizzarra II, 6) 'Could you shut up, at least as a favour?'

In the $19^{\text {th }}$ century, typical politeness formulae to soften bald imperatives are la supplico 'I beg you', abbia la bontà 'have the kindness', among others, but, crucially, per favore is not documented yet (see Paternoster and Saltamacchia, 2017 for a comprehensive discussion). In a letter written by Leopardi in 1823 per favore still functions as a PP qualifying 'as an act of kind carefulness' the action of portare 'to bring':

(18) Il corriere l'ha portato per favore, ma dicendo che lo lascerebbe alla posta (Leopardi, Lettere, 296)

1 http://www.bibliotecaitaliana.it, http://www.liberliber.it; both accessed: January 2018. 
'The courier brought it as a favour, but saying that he would have left it at the post office'

The first instances of routinized per favore as a PM date back to the late 1800s: in (19), it mitigates a non-clausal request:

(19) s'avvicinava a un altro: “Un soldo, per favore?" (De Roberto, I viceré, 3, 6.65) 'he was approaching another person: "A penny, please?"

The first indisputable literary examples are found in the early 1900s, in Serao (ex. 20) and above all in Pirandello, whose novels and plays provide numerous instances where per favore and per piacere function as fully fledged PMs (ex. 21). Note that the frequent comma is a clear sign of the parenthetic status of the PM:

(20) piove, e Toto s'è portato l'ombrello. Per favore, me lo prestereste l'ombrello vostro? (Serao, I, 896)

'it rains, and Toto has taken the umbrella. Please, could you lend me your umbrella?'

(21) stia tranquilla, e se ne vada, per piacere! (Così è se vi pare III, 8)

'be quiet and go away, please!'

The development discussed so far is confirmed by the ngram viewer chart on the frequency of per favore in Google Book's Italian text corpus including sources printed between 1500 and 2008 (Figure 1). Note that during the time span between 1500 and 1750, frequencies of per favore are very low: this is represented by a square line. Note also that a closer look at the occurrences of per favore in the texts written between 1828 and 1846 revealed that this expression is used with the meaning 'in favour of', a usage which decreases between 1850 and 1900. The frequency of per favore then starts to mount again in the XXI century as a pragmaticalized PM. 


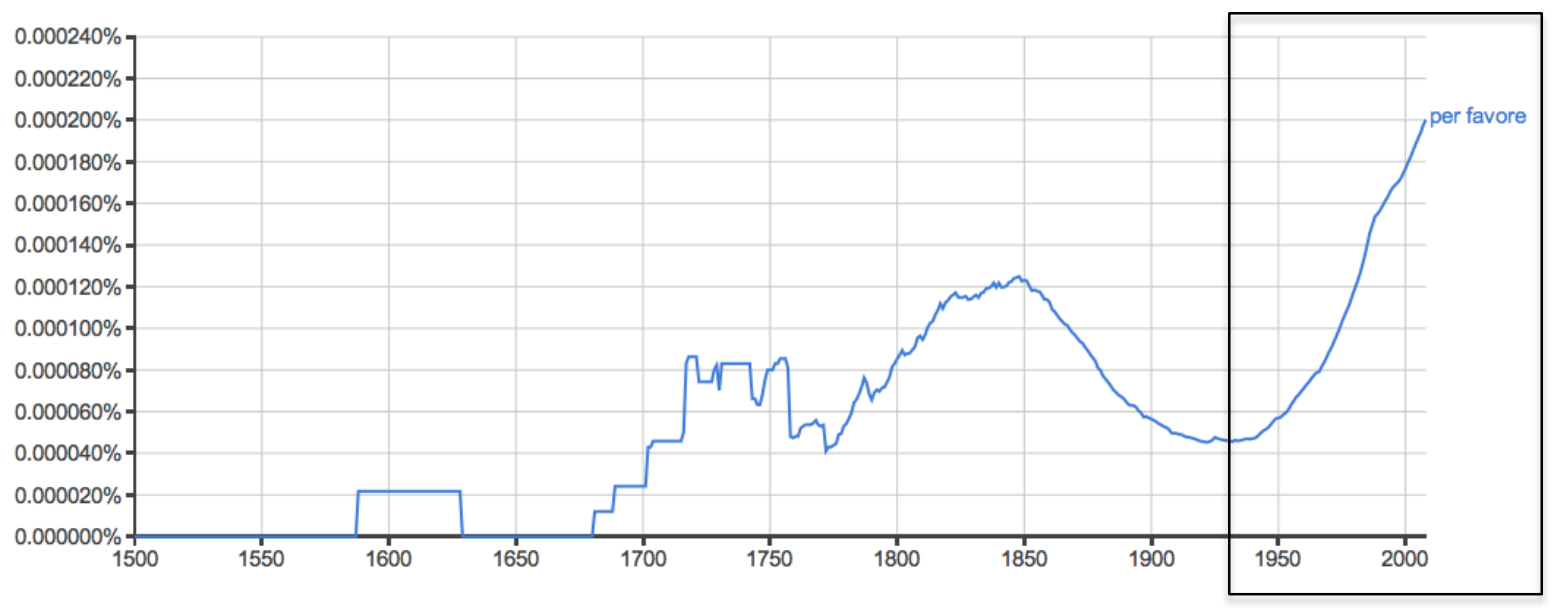

Figure 1. Ngram viewer chart of per favore

Morphosyntactic and functional dependencies of per favore changed accordingly. Until the late $1800 \mathrm{~s}$, per favore was a modifier qualifying the action performed by the VP; from the early 1900s, it started functioning as a PM with scope over the whole directive act, along the lines shown in (22).

(22) $\left[\text { chiedo }[\text { per favore }]_{\mathbf{P P}}\right]_{\mathbf{V P}}$ [venga con me ] VP- ORDER [per favore] PP - POLITENESS MARKER

Together with its increase in scope, per favore and variants underwent semantic bleaching: when functioning as a PM, it is no longer compositionally analyzed as 'in terms of a favour'. Therefore, Italian PMs underwent a typical life cycle from a lexical element to a parenthetical expressing attention to the interlocutor's face needs, along the cline of increasing subjectivity CONTENT $>$ CONTENT/PROCEDURAL $>$ PROCEDURAL (Traugott and Dasher, 2002: 281). Parallel to that, the markers became more mobile syntactically: when used in their literal sense as a modifier of the VP, they typically follow it. As PMs, by contrast, they mostly preface polite requests, thus gravitating towards the left periphery (ex. 20), but occurring in virtually all positions, including the final placing, typically with urgent commands (ex. 21). We will come back to this point in Section 4: before turning to the analysis, however, a few words on the corpus and the methodology are needed. These are provided in Section 3.

\section{Data and methodology}


The present study is based on data drawn from the Paisà corpus of Italian web texts, a large collection of approximately 388,000 documents from 1,067 different websites and blogs, totalling over 250 million tokens and gathered through web crawling (Lyding et al., 2014). ${ }^{2}$ Given the nature of the data considered, it is useful to say a few words on the characteristics of electronic discourse and im/politeness in digital interactions.

As is well known, computer-mediated discourse altogether lacks the non-verbal behaviors typically associated with emotions and personal stance, and this may correlate with a greater use of explicit linguistic (including graphical) strategies expressing both positive and negative attitudes towards the interlocutor(s) or the conveyed content. As far as negative stance is concerned, users can interact anonymously and are therefore less committed to the potential negative implications of their impolite behaviour. These two facts considered together make digital contexts such as blogs and forums particularly good sites to explore a variety of identity construction strategies connected to facework and (im)politeness phenomena (see e.g. Locher, 2014).

It has also been pointed out that users with anonymous or uncertain identity can violate 'politic' behaviour, social conventions and politeness norms as a creative mode of entertainment, exploiting the potentialities of a virtual environment with basically no risks (see e.g. Leech, 2014: 235); in turn, forum users are more tolerant to face-threats than are speakers in face-to-face interactions (Ehrhardt, 2014). This is why a growing body of research is focusing on im/politeness phenomena in emails and on discussion boards. Graham (2017: 270) offers an updated summary, and underlines that because of the breadth of these formats, continued research is needed to explore emergent phenomena related to different languages and interactional genres, communities of users, and varying types of platforms. This is even more the case with respect to Italian, a language for which no systematic research on (im)politeness in electronic discourse has been carried out, an exception being Thaler (2014). In her study, Thaler analyzes online comments from a popular Italian portal for cooking recipes and shows that negative evaluations are systematically mitigated through three main strategies, namely agreeing before disagreeing, giving explanations, and pointing to subjectivity. Her conclusion is that normally negative evaluations need to be softened to be socially acceptable, and this is the case also in computer-mediated discourse.

This tendency, however, does not hold in many online comments considered in the present

2 More precisely, 119,000 documents come from blogs, e.g. www.tvblog.it (9,088 pages), www.motoblog.it $(3,300)$, www.ecowebnews.it $(3,220)$, www.webmasterpoint.org $(3,138)$ (Lyding et al., 2014: 37). 
study, where, as we will see, potentially face-threatening acts such as criticism and disagreement are more often reinforced rather than mitigated. The setting of electronic communication may indeed affect facework and (im)politeness concerns in different ways. Firstly, the topic can influence the relationships between users: as we will see, some fields of interest discussed in the blogs I surveyed, like cars and motorbikes, football, politics, and TV, tend to trigger verbal aggression and conflict more often than the above-mentioned case of cooking recipes. Second, the format of the discussion may affect the subjective attitudes of the participants in different ways. Online evaluations of cooking recipes, for instance, are cooperatively construed as useful reviews for other potential users of the community. Feedback is written in isolation and presumably not checked afterwards. Blog posts, by contrast, can prompt virtual conversations in which several participants are simultaneously online, interacting in back-and-forth exchanges where differences of opinion and disputes naturally arise. These observations point to potential limitations of the data set investigated here, since is it typical of these blogs that the users are likely to criticize more than to request, as we will see in the data analysis in Section 4, and that they use a lower style register (this probably influencing the scarce use of the more formal per cortesia in the corpus: see Table 2).

Bearing these cautionary notes in mind while drawing on the online written data described so far, my procedure was to check all the occurrences of per favore/piacere/cortesia in the corpus and to classify all the instances according to the four directive subtypes in which they occur, namely polite requests (cf. ex. 29 below), prohibitions (ex. 32), impolite commands (ex. 30), and extra-clausal uses where per favore/piacere/cortesia, often prefaced by ma 'but', function as markers of disagreement (ex. 25; see Table 2).

\begin{tabular}{|l|c|c|c|}
\hline & (ma) per favore & (ma) per piacere & (ma) per cortesia \\
\hline POLITE REQUESTS & 243 & 26 & 31 \\
\hline PROHIBITIONS & 157 & 10 & 10 \\
\hline IMPOLITE COMMANDS & 135 & 17 & 18 \\
\hline DISAGREEMENT MARKERS & 222 & 68 & 8 \\
\hline Total & $\mathbf{7 5 7}$ & $\mathbf{1 2 1}$ & $\mathbf{6 9}$ \\
\hline
\end{tabular}

Table 2. Distribution of Italian PMs in the Paisà corpus across directive subtypes

Some preliminary observations emerge from the data: first, per favore is by far the most frequent PM in the corpus - which mirrors the present situation in Contemporary Italian. Second, the distribution of ( $m a$ ) per piacere and ( $m a$ ) per cortesia across different directive subtypes is almost identical, with the exception of their frequency as disagreement markers: 
(ma) per piacere is used much more often with this function, perhaps because it is currently undergoing a process of specialization in this respect (Section 4). This ties in with the third point, namely that both (ma) per favore and (ma) per piacere occur strikingly often in confrontations where they act as non-integrated markers of disagreement. Next come prohibitions, and impolite commands (with different frequencies for the three forms). These data show that a pragmatic reversal has definitely taken place in Italian. This will be the topic of Section 4.

\section{The pragmatic reversal of per favore, per piacere and per cortesia in Contemporary Italian}

As anticipated in Section 1, the typical contexts where Italian PMs developed impolite functions are impolite commands, prohibitions, and quotative constructions expressing a content with which the writer disagrees. It has to be stressed at this point that when occurring in these patterns per favore/piacere/cortesia are typically prefaced by the adversative conjunction $m a$ 'but', thus giving rise to a specialized construction expressing impolite dissent and rebuttal of the interlocutor's claim. This should come as no surprise, given the adversative meaning of $m a$. Adversative expressions typically imply the bringing together of two opposing views (Beeching 2007: 91), and this explains why, at a discourse level, $m a$ frequently functions as an interactional move of contrast in terms of a turn-taking or turnleaving device, and topic-change marker, also with counter-expectational value (the interlocutor expects to continue the ongoing topic, but the speaker changes it). Moreover, it can strengthen the impositive force of a request if it prefaces it (e.g. mi lasci in pace 'can you leave me alone?' is much stronger if an initial $m a$ is added). Its regular occurrence in confrontational uses of per favore/piacere/cortesia has to be understood precisely in these terms, with $m a$ further corroborating the meaning of interactional contrast. Table 3 lists the occurrences of the PMs considered, giving an indication of the cases in which they are prefaced by ma: $31 \%$ of cases with per favore and even $52 \%$ with per piacere.

\begin{tabular}{|c|c|c|c|}
\hline $\begin{array}{c}\text { POLITENESS } \\
\text { MARKER }\end{array}$ & ALONE & WITH MA & $\begin{array}{c}\% \text { OF TOTAL } \\
\text { CASES }\end{array}$ \\
\hline (ma) per favore & 519 & 238 & $31 \%$ \\
\hline (ma) per piacere & 58 & 63 & $52 \%$ \\
\hline (ma) per cortesia & 59 & 10 & $14 \%$ \\
\hline
\end{tabular}

Table 3. Occurrences of (ma) per piacere/favore/cortesia in the Paisà corpus 
A detailed inspection of the directive subtypes in which ma occurs most often confirms its role in reinforcing the confrontational value of the PMs in the two most conflictive directives. Its occurrence dramatically decreases, however, if per favore 'sincerely' mitigates a request (Figure 2).

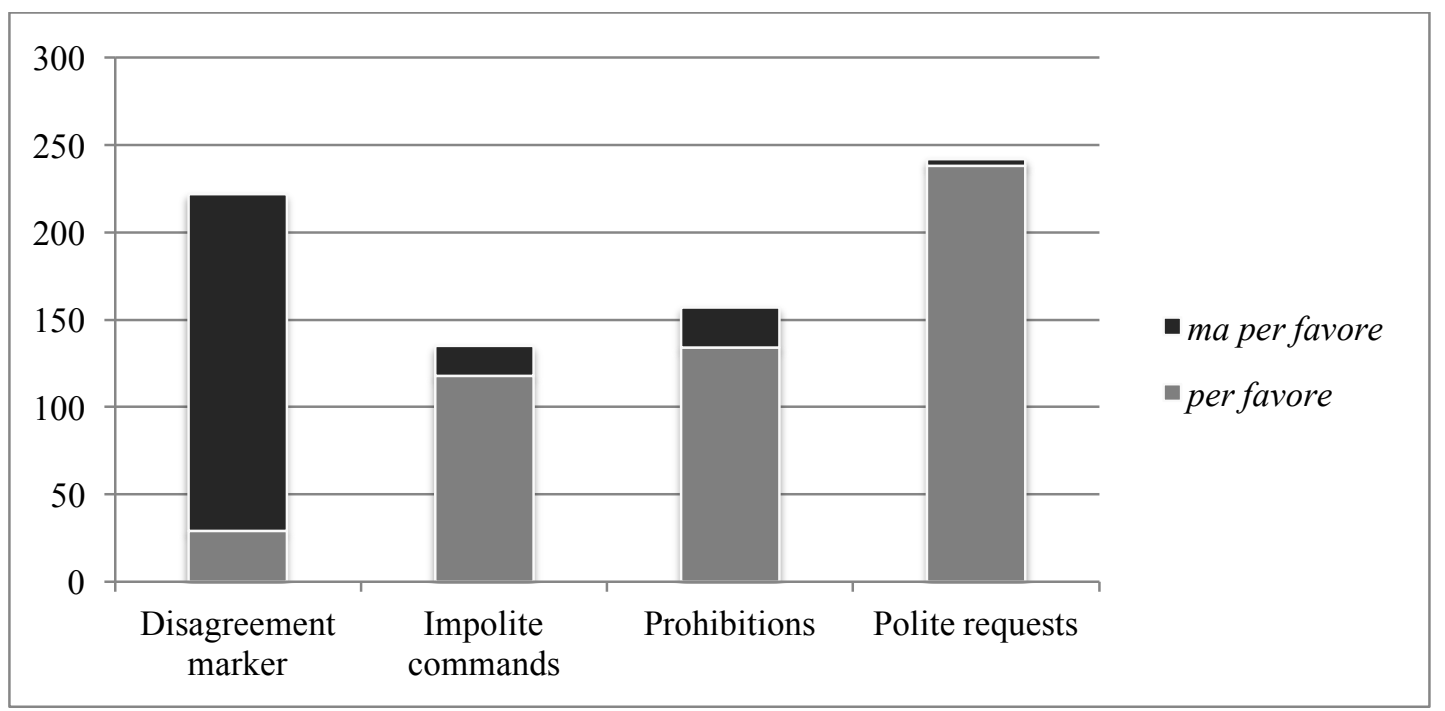

Figure 2. Occurrences of per favore prefaced by $m a$ in different directive subtypes

A very similar picture emerges from the data concerning the combination of $m a$ and per piacere, which testifies to the key role played by $m a$ in the specialization of these forms as markers of disagreement (Figure 3).

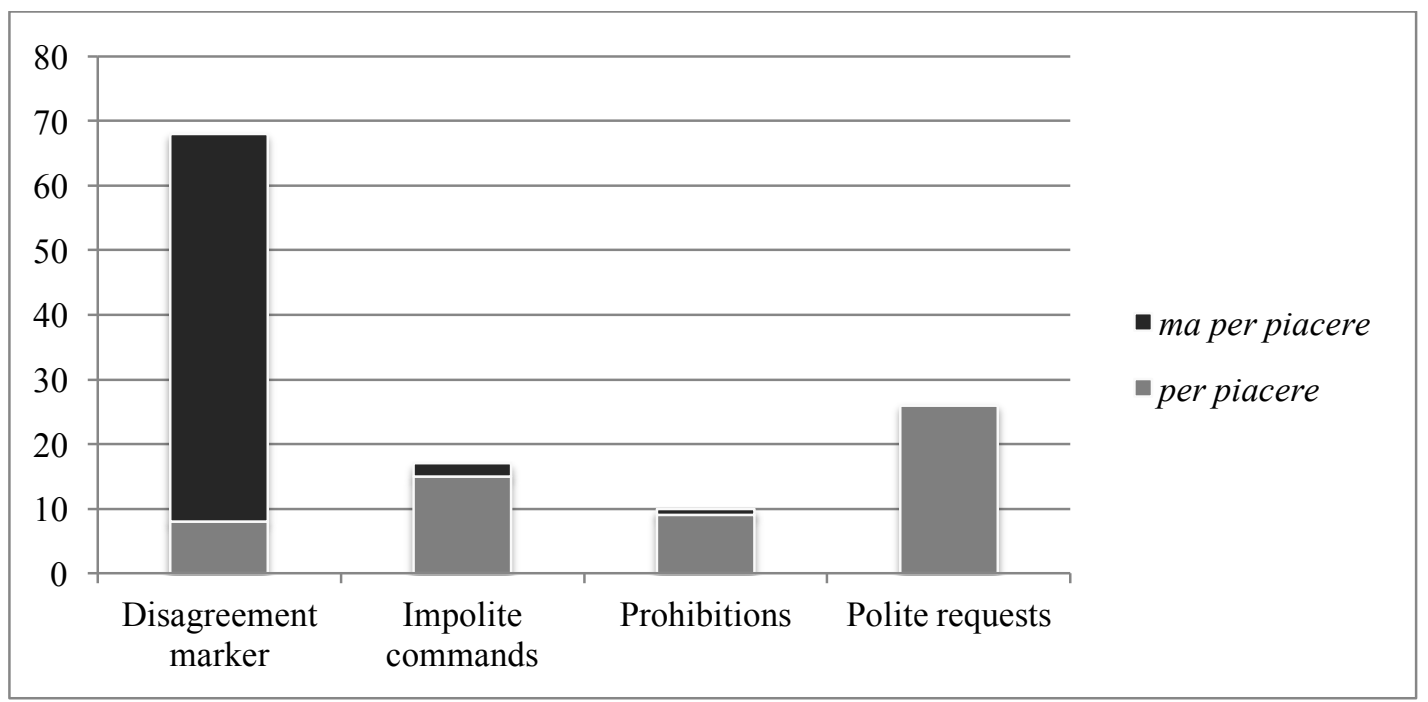

Figure 3. Occurrences of per piacere prefaced by ma in different directive subtypes 
More specifically, the extra-clausal pattern of disagreement featuring ma plus per favore, per piacere or per cortesia is made up of the following elements:

\begin{tabular}{|c|c|}
\hline eporting th & $\begin{array}{l}\text { (ma) per favorel } \\
\text { piacere/cortesia }\end{array}$ \\
\hline
\end{tabular}

An example exhibiting all three constitutive parts is given in (23), in which the quotative construction is underlined and the additional criticism, in form of an expression of mockery, is put in italics:

(23) cioe' se una persona e' felice e si sta divertendo un mondo a giocare e' da anormali? MA per favore...vai a fare lo psicologo da un'altra parte figliolo. hahahaha 'so if a person is happy and has the time of his life while playing that's abnormal behaviour? BUT please...go do your psychologist's act somewhere else kid. hahahaha'

Frequent quotative constructions include proper citations between inverted commas (ex. 24, and 5 above), rhetorical echo-questions (25-26), and reporting clauses featuring the verb dire 'to say' (27-28):

(24) Quindi falla finita con le cazzate. "siete solo 5": ma per favore... 'let's cut the bullshit then. "there's only five of you": but please...'

(25) Io no e Standing Ovation sarebbero capolavori? Ma per favore... 'So you think Io no and Standing Ovation are masterpieces? but please...'

(26) Chiambretti come Letterman?.... ahahahahahahahahahah, ma per favore!!! 'Chiambretti like Letterman? ... ahahahahahahahahahah, but please!!!'

(27) E mi venite a dire che Tor Vergata è ok.. ma per piacere.. 'And you're telling me that Tor Vergata is ok... but please..'

(28) E poi tutti a dire che House è bellissimo, ma per favore. 'And everyone keeps saying that House is great, but please.'

Some readers may have noted at this juncture that these constitutive elements tend to occur in a recurrent preferred order, featuring the quotative construction in initial placing, followed by an extra-clausal (ma) per favore/piacere/cortesia as a closing device signalling disagreement. This is an important point, since position turns out to be connected with similar, but distinct functions of the 'reversed' markers. Indeed, an analysis of the position of (ma) per favore/piacere/cortesia in the utterance showed that they tend to occupy initial position when 
mitigating a request, i.e. in their prototypical and 'sincere' polite use. This is probably because by prefacing the request with a PM, the writer plans to soften the directive from the outset, showing his consideration for the interlocutor's face needs. If we consider the total number of polite requests mitigated by per favore in the Paisà corpus, it is significant that in $49 \%$ of cases (53 out of 109) the PM occurs in initial position (cf. ex. 29) and takes final position only in 18\% (20 out of 109). Middle position, typically occupied by parentheticals that lower the speaker's commitment, is another frequent option (33\%). By contrast, the data show that when used impolitely per favore clearly gravitates towards the right periphery (RP), as a sort of afterthought which exacerbates rather than mitigates the directive content (ex. 30: note the sarcastic use of caro 'dear' in reference to the former Italian prime minister Gentiloni).

(29) per favore realizzatemi questo desiderio.. ciao ciao aspetto una vostra risposta...

'please grant me this wish...bye bye let me know...'

(30) Quindi caro Gentiloni apri gli occhi per favore

'Then my dear Gentiloni open your eyes please'

Moreover, in the corpus there are three occurrences of another positional option, in which per favore, always prefaced by $m a$, occurs as an independent intervention in a highly critical rebuttal of the interlocutor's point of view, as in (31):

(31) 13 apr 2007 - 15:51 - \#10

per chi non ha internet o per la gente comune, che si installino una bella parabolica e guardino programmi dalla Spagna o altro, non importa se non capiscono niente, ma e' sempre meglio di questa ca-ga-ta che si chiama italian tv.

passo e chiudo.

13 apr 2007 - 15:53 - \#11

ma per favore..

'for those who don't have the internet or for common people, they should install a dish and watch Spanish programs or other things, it doesn't matter if they don't understand anything, it's better than this c-r-a-p called Italian tv. over and out.' 'but ple-e-e-ase..'

This emerging pattern provides evidence for a high degree of routinization of ma per favore as a free-standing marker of disagreement with a holophrastic value. Table 4 gives detailed frequencies on polite vs. impolite functions of $(\mathrm{ma})$ per favore and its position.

\begin{tabular}{|l|l|l|l|} 
LP & middle & RP & independent \\
\hline
\end{tabular}




\begin{tabular}{|l|c|c|c|c|c|c|c|c|}
\hline & & with $m a$ & & with $m a$ & & with $m a$ & & with $m a$ \\
\hline $\begin{array}{l}\text { MARKERS OF } \\
\text { DISAGREEMENT }\end{array}$ & 10 & 11 & & & 19 & 179 & & 3 \\
\hline IMPOLITE COMMANDS & 39 & 17 & 12 & & 67 & & & \\
\hline PROHIBITIONS & 62 & 23 & 16 & & 56 & & & \\
\hline POLITE REQUESTS & 103 & 5 & 57 & & 78 & & & \\
\hline
\end{tabular}

Table 4. Functions and position of ( $m a$ ) per favore

The data in Table 4 shows that when used as a 'true' PM, per favore tends to occur in the LP, where it functions as a procedural frame signalling that the upcoming directive is the most softened possible. However, per favore occur in the RP in 78 cases and this may be related to the fact that in polite requests the opportunity for the interlocutor of refusing to comply can vary and the PM can alternatively be added after the request, as an unplanned repair (see Mazzon, 2017: 297 for similar remarks on I'm afraid as extra-structural afterthought). In impolite commands, there is a slight preference for the RP. In turn, the final placing is greatly preferred when (ma) per favore functions as a marker of disagreement after a quotative construction: it is placed in the RP in $91 \%$ of cases (201 out of 222; see ex. 24 to 28 above). This preference for the right margin ties in with the typical intersubjective and modalizing function played by elements at the RP (see Beeching and Detges, 2014). These data are summarized in Figure 4.

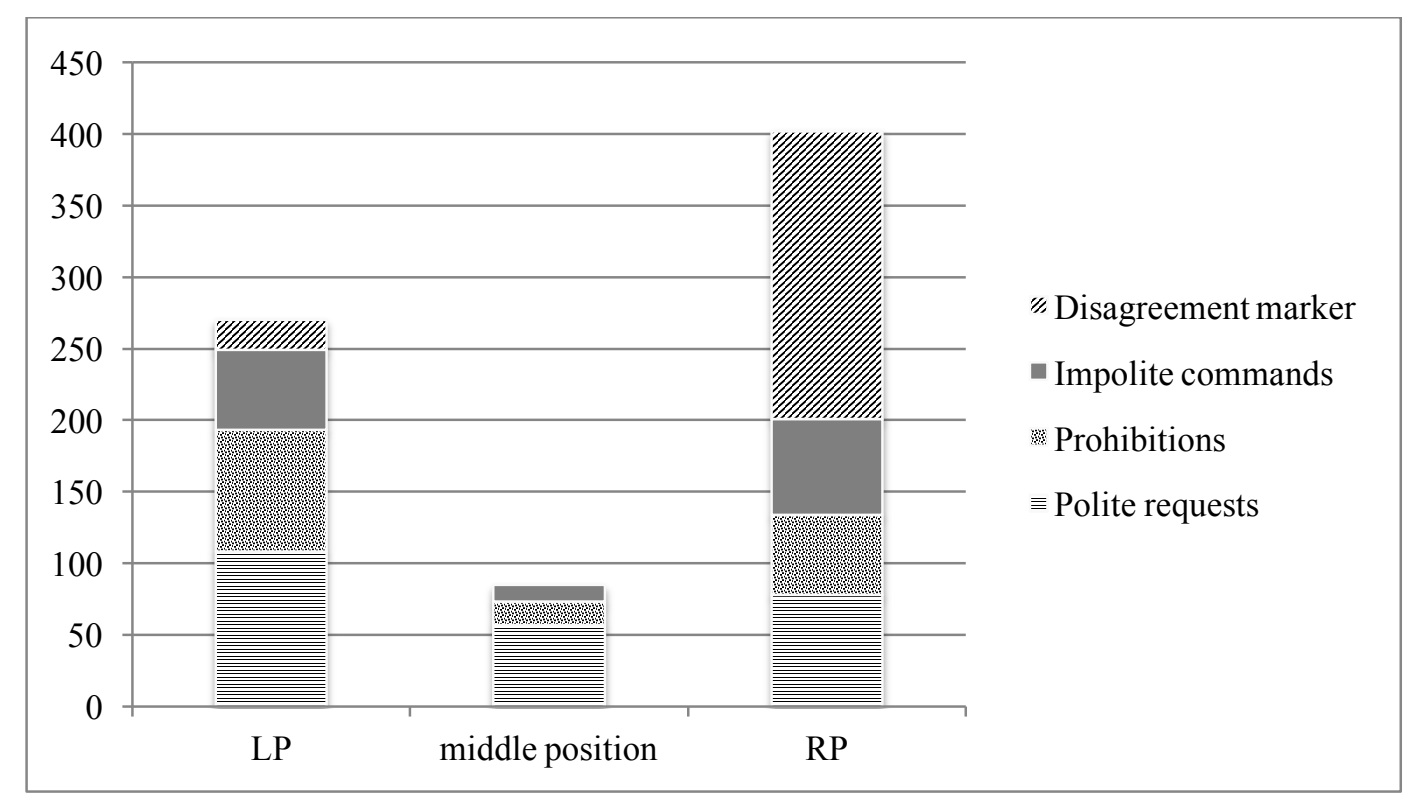

Figure 4. Functions and position of ( $\mathrm{ma}$ ) per favore 
As briefly mentioned above, the data on $(\mathrm{ma})$ per piacere point to a very similar formal and functional characterization: it is mostly used in conflictive contexts, with a frequency peak $(56 \%)$ as an extra-clausal marker of disagreement in the RP (Table 5).

\begin{tabular}{|l|c|c|c|c|c|c|}
\hline & \multicolumn{2}{|c|}{ LP } & \multicolumn{2}{c|}{ middle } & \multicolumn{2}{c|}{ RP } \\
\hline & & with $m a$ & & with $m a$ & & with $m a$ \\
\hline DISAGREEMENT MARKER & 1 & & & & 7 & 60 \\
\hline IMPOLITE COMMANDS & 5 & 2 & 2 & & 8 & \\
\hline PROHIBITIONS & 4 & 1 & & & 5 & \\
\hline POLITE REQUESTS & 14 & & 7 & & 5 & \\
\hline
\end{tabular}

Table 5. Functions and position of ( $\mathrm{ma}$ ) per piacere

The distribution outlined in Table 5 suggests an ongoing process of routinization which is leading ma per piacere to acquire an exclamatory, interjection-like status expressing the writer's emotions and subjective attitude. Further evidence for this emergent use comes from a very negative TripAdvisor comment about a hotel stay (Figure 5). The review is extremely trenchant and criticizes almost all services (check-in and check-out, breakfast, airport shuttle), summarizing the very bad experience with a title made up of a holophrastic ma per piacere expressing indignation and disappointment.

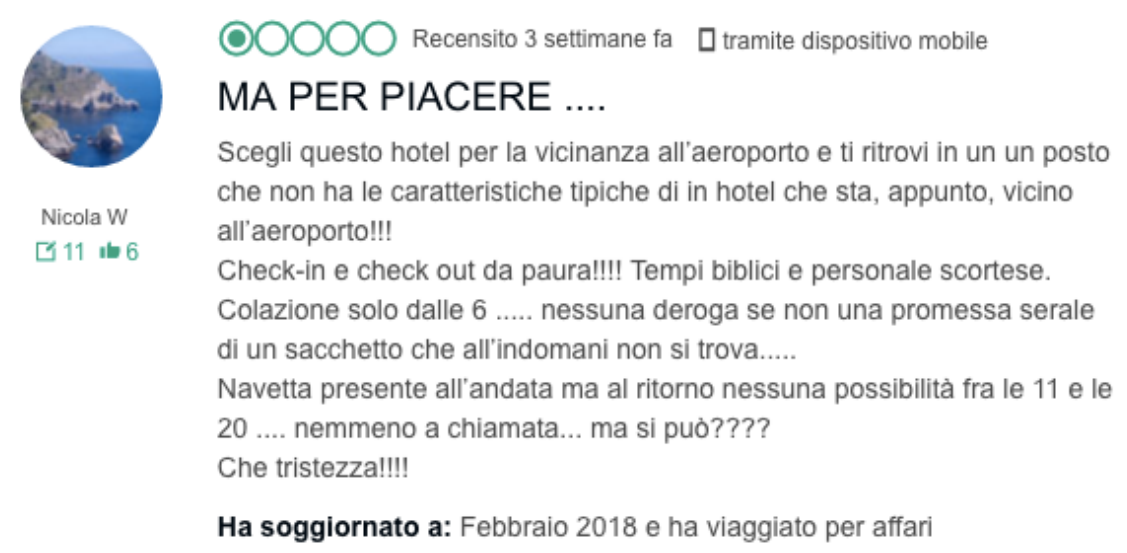

Figure 5. A TripAdvisor review (www.tripadvisor.it, posted on 02/2018)

The pragmatic specialization of ma per piacere in terms of reversed marker of disagreement also emerges from a comparison of relative frequencies of the three markers prefaced by ma occurring in the directive subtypes considered, which are shown in Figure 6 (with absolute frequencies normalized for 1 million words). The data suggest that, on the one hand, the $m a+$ per favore/piacere/cortesia pattern is on its way towards routinization as extra-clausal marker of disagreement and, on the other, ma per piacere is the most likely element to do so, 
followed by ma per favore and then by ma per cortesia (note, however, that due to the raw frequencies available for ma per piacere in the corpus surveyed this claim needs to be substantiated by further research).

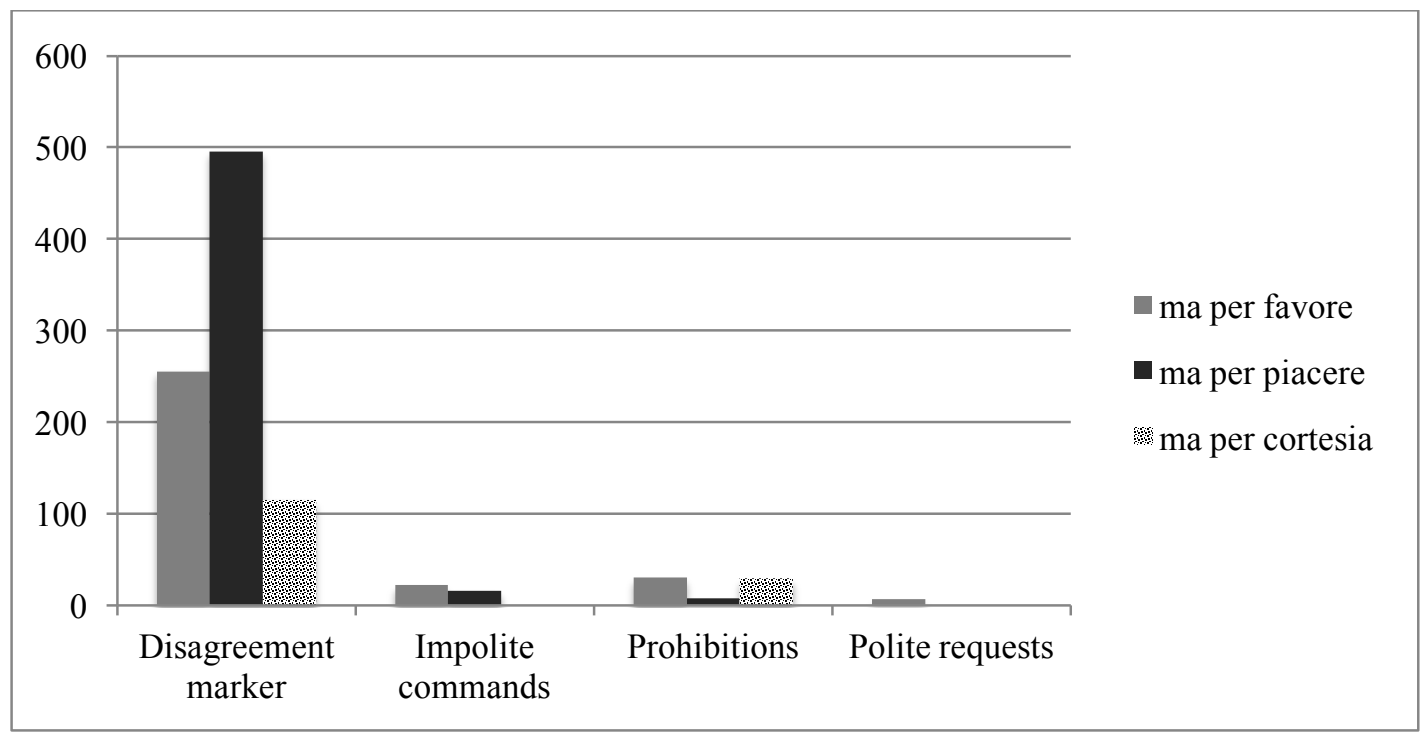

Figure 6. Distribution of the $m a+$ PM pattern in directive subtypes (relative frequencies)

As Figure 6 shows, per cortesia is the least frequently attested PM in the corpus (69 tokens only). It is prefaced by $m a$ in $14 \%$ of cases, thus playing quite a marginal role within the reversal, although participating in the general trend (Table 6). In one of its typical contexts, it reinforces the urgency of prohibitions in the RP:

(32) tu che ti ergi a difensore del popolo nomade, impara per primo a non giudicare gli altri e a non usare determinati epiteti, per cortesia. Chiaro? 'You set yourself up as a defender of nomads, learn first not to judge others and not to use certain epithets, please. OK?'

\begin{tabular}{|l|c|c|c|c|c|c|}
\hline & \multicolumn{2}{|c|}{ LP } & \multicolumn{2}{c|}{ middle } & \multicolumn{2}{c|}{ RP } \\
\hline & & with $m a$ & & with $m a$ & & with $m a$ \\
\hline DISAGREEMENT MARKER & & & & & & 8 \\
\hline IMPOLITE COMMANDS & 5 & & 2 & & 11 & \\
\hline PROHIBITIONS & 2 & 2 & 4 & & 2 & \\
\hline POLITE REQUESTS & 9 & & 16 & & 8 & \\
\hline
\end{tabular}

Table 6. Functions and position of (ma) per cortesia

We now have a more detailed picture that might account for the pragmatic reversal undergone by per favore and its variants. In my view, impolite values first developed in the grey area 
between polite requests and impolite commands with a progressively decreasing possibility of noncompliance on the part of the interlocutor. It is likely that the switch from a predominantly mitigating to a predominantly strengthening function precisely took place along this continuum. Directives specifically aimed at challenging the interlocutor's point of view presumably played a major role in this respect. The corpus data I considered do indeed suggest that the preferred locus for the switch is the one presented in (33) to (39), where the writer prevents the interlocutor from saying something with which s/he will disagree: typical silencers in this respect are to shut up (33-34) and/or not to talk bullshit (Italian stronzate, cazzate, or minchiate, euphemistically shortened in 35 to 37 ).

(33) Ma per favore state muti che fate più figura...

'But please shut up and you'll make a better impression...'

(34) ora sei attore e guadagni 20milioni di euro per film quindi stai zitto per favore 'now you're an actor and you earn $€ 20$ million per movie so shut up please'

(35) non dite S., per favore: mettersi un aggeggio del genere non può essere nè comodo, nè igienico

'don't talk b., please: wearing such a device cannot be comfortable nor hygienic'

(36) quindi finiamola per favore... finiamola di dire un sacco di stronz $* * *$. 'then let's stop here please... let's stop talking a load of $\mathrm{cr} * * *$ '

(37) Possibile che incontrato uno che rompe mo ne devono fare le spese tutti! e no, eh!...non diciamo minc....ate!!! per favore!!

'When you meet someone who annoys you, does that mean we all end up paying the bill! no way! let's cut the bul...it!!! please!!'

(38) Ma per cortesia, non diciamo cazzate . 'then let's end it here please... let's stop talking a load of crap'

The excerpt in (39) combines two reversed uses of per favore, which firstly works as an extraclausal marker of disagreement prefacing the refused argument selvaggi è un bel film 'selvaggi is a nice movie' introduced by the recurrent quotative construction chi ha coraggio di dire 'who would dare to say' (shown also in ex. 7 above) and then stresses the urgency of a silencer:

(39) E poi per favore chi ha coraggio di dire che selvaggi è un bel film...vi prego per favore state zitti piuttosto ma nn dite ste stronzate. 
'And then please who would dare to say that selvaggi is a nice movie...I beg you please shut up rather but don't talk such bullshit'

Now, if this line of reasoning is on the right track, extra-clausal uses of (ma) per favore and its variants in the RP should be interpreted as elliptical segments implying a broader impolite silencer along the lines of the pattern given in (33) to (39), in the form (but) please (shut up/don't talk bullshit). At a certain point, such underlying content came to be metonymically condensed in the marker which recurrently occurred before or after the request, as a result of a routinized use as a courtesy formula, and which in the end acquired a new conventionalized meaning of impolite urgency. Examples (40) and (41) illustrate this last stage, featuring instances of extra-clausal ( $\mathrm{ma}$ ) per favore in contexts where - and this is a very crucial point there is no potentially face-threatening element to be mitigated. Thus, the markers under scrutiny constitute interventions on their own, functioning as signals of the speaker's negative attitude towards what the interlocutor has said: as a free-standing marker in (40) and parenthetically, upgrading the urgency of an aggressive question in (41).

(40) 13 ago 2008 - 14:51 - \#8 Ragazzi, beh.. istintivamente viene da colpevolizzarla, ma facendo un ragionamento ha anche ragione. [...]nelle ultime stagioni il suo personaggio era al centro della scena. E poi 10-20 mila euro.. beh mi pare francamente poco O_o.

13 ago $2008-15: 40-\# 9-1$ punto

13 ago 2008 - 16:11 - \#10 ma per favore: sta bruttona (e sottolineo, burttone nonostante le 400 operazionestetiche) dovrebbe ringraziare lo straricco padre se la fanno ancora lavorare

'Guys, well...instinctively I want to blame her, but when you think about it she's also right. in the last seasons her character took centre stage. And 10-20 thousand euro...well frankly it isn't very much O_o.'

'but ple-e-e-ase: this fugly (and I emphasize ugly bot despite 400 reconstructive operations) should thank her loaded dad if she still has a job'

(41) E poi , per favore, il Concilio Vaticano II cosa c'è stato a fare?

'And, please, what was the point of the second Vatican council?'

These uses can be compared to that of free-standing please analyzed by Aijmer (2015: 141142), who noted that, when used in isolation, please "has an exclamatory quality".

\footnotetext{
${ }^{3}$ Yet another interesting feature of this excerpt is the reinforcement of per favore by means of a second politeness formula, vi prego 'I beg you', which in my view is partially undergoing pragmatic reversal in Contemporary Italian. The two adjacent markers point to the same impolite interpretation.
} 
The analysis carried out in this paper allows us to conclude that Italian ma per favore and $m a$ per piacere have reached the most advanced stage in the reversed pragmaticalization as freestanding holophrastic markers of disagreement.

\section{Concluding remarks}

In this paper we have seen how the PPs per favore, per piacere and per cortesia gradually pragmaticalized in the history of Italian, starting as modifiers of VPs such as chiedere 'to ask' and portare 'to bring', and that their conventionalization as PMs is a recent phenomenon ( $\S$ 2). In the last few years, however, these markers have undergone a new process of functional enrichment leading them to acquire impolite functions, which we labelled 'pragmatic reversal' after Mazzon (2017). The point made in this paper is that the motivation behind this reversal rests precisely on the conventionalized value displayed by these politeness formulae, deeply embedded within the 'politic' level of interpersonal communication. It is their high degree of routinization which probably triggered a gradual process of semantic and pragmatic bleaching, and, subsequently, made these forms prone to take over new, related - although opposed - values in their typical domain of use, that of directives. Therefore, and perhaps paradoxically, the partial loss of their 'neutral', conventional value paved the way for the acquisition of new confrontational functions. This led to the conventionalization of an emergent pattern with its own characteristics: formally, it features an (originally) politeness marker mostly prefaced by $m a$; positionally, it gravitates towards the RP; structurally, it is often used as an extra-clausal adjunct; pragmatically, it strengthens the illocutionary force of directives or conveys disdain and disagreement (§ 4).

Crucially, the emergence of the reversal seems to be inherently connected to highly colloquial registers, such as those evidenced in the online texts drawn from blogs and forum chats scrutinized in this study $(\S 3)$. In particular, blogs and other digital platforms constitute informal contexts in which users virtually have the same prestige and social status, and often behave as 'experts' on a specific topic, feeling free to harshly criticize others - this also being favoured by their anonymous identity, which can lead to the violation of 'politic' behaviour as a form of creative entertainment. Such communicative registers probably fostered textspecific pathways of development, which may eventually spread to larger contexts. This 
substantiates an interesting claim earlier made by Aijmer (2013: Ch. 2), who showed that there were crucial differences between the various ways in which English well is used in different text-types.

The data analyzed in this paper also show that 'reversals' that lead courtesy formulae to acquire challenging values are not randomly isolated, but constitute an interesting pattern of pragmatic switch involving a number of equifunctional forms in different languages. Needless to say, the present analysis is open to further investigation, both intra-linguistic (on other Italian politeness formulae which seem to have embarked on similar paths) and interlinguistic, in order to acquire more data on this impoliteness-driven reversal and possibly make generalizations about its stages and the factors in play in different languages.

\section{Acknowledgments}

I would like to thank Kate Beeching, Chiara Ghezzi, Piera Molinelli, and James Murphy for insightful remarks and suggestions. In particular, I owe my gratitude to Kate Beeching for interesting and stimulating discussions at different stages. This paper has also benefited from remarks and suggestions from two anonymous reviewers, whom I warmly thank.

\section{References}

Aijmer, Karin, 2013. Understanding Pragmatic Markers. Edinburgh, UP.

Aijmer, Karin, 2015. "Will you fuck off please". The use of please by London teenagers. Sociocultural Pragmatics 3, 127-149.

Barron, Anne, 2008. The structure of requests in Irish English and English English. In: Schneider, K. P. \& A. Barron (Eds.), Variational Pragmatics. A focus on regional varieties in pluricentric languages. Amsterdam, Benjamins, pp. 35-67.

Bazzanella, Carla, 2003. Discourse Markers and Politeness in Old Italian. In: Held. G. (Ed.), Partikeln und Höflichkeit. Wien, Peter Lang, pp. 247-268.

Beeching, Kate, 2007. A politeness-theoretic approach to pragmatico-semantic change. Journal of Historical Pragmatics 8 (1), 68-108.

Beeching, Kate, Detges, Ulrich, 2014. Introduction. In: Beeching, K \& U. Detges (Eds.), Discourse Functions at the Left and Right Periphery. Leiden, Brill, pp. 1-23.

Culpeper, Jonathan, 2011. Impoliteness: Using language to cause offense. Cambridge, CUP.

Dressler, Wolfgang, Barbaresi, Lavinia Merlini, 1994. Morphopragmatics. Diminutives and Intensifiers in Italian, German and Other Languages. Berlin, de Gruyter.

Ehrhardt, Claus, 2014. Politeness and Face Work in German Forum Communication. In: Bedijs, K., Held, G. \& C. Maaß (Eds.), Face Work and Social Media. Münster, LITVerlag, pp. 83-107.

Ghezzi, Chiara, 2015. Thanking formulae. The role of language contact in the diachrony of Italian. In: Consani, C. (Ed.), Contatto interlinguistico fra presente e passato. Milano, LED, pp. 315-341. 
Ghezzi, Chiara, Molinelli, Piera, 2014. Pragmatic markers from Latin to Italian (Lat. quaeso and It. prego): the cyclic nature of functional developments. In: Ghezzi, C. \& P. Molinelli (Eds.), Discourse and pragmatic markers from Latin to the Romance languages. Oxford, OUP, pp. 61-85.

Graham, Sage. 2017. Politeness and Impoliteness in Social Media. In: Hoffmann, C. \& Bublitz, W. (Eds.), Pragmatics of Social Media. Berlin, de Gruyter, pp. 459-491.

Held, Gudrun, 2005, Politeness in Italy: The Art of Self-representation in Requests. In: Hickey, L. \& M. Stewart (Eds.), Politeness in Europe. Clevendon, Multilingual Matters, pp. 292-305.

Held, Gudrun, 2010, Supplica la mia parvidade...Petitions in Medieval Society - a Matter of Ritualised or First Reflexive Politeness?. Journal of Historical Politeness 11 (2), 194-218.

Leech, Geoffrey, 2014. The Pragmatics of Politeness. Oxford, OUP.

Locher, Miriam A., 2014. Introduction: Politeness and impoliteness in computermediated communication. Journal of Politeness Research 6, 1-5.

Lyding, Verena, et al., 2014. The PAISÀ Corpus of Italian Web Texts. Proceedings of the 9th Web as Corpus Workshop, Association for Computational Linguistics, pp. 3643.

Mazzon, Gabriella, 2017. Paths of development of English DMs: (inter)subjectification, deontic reversal and other stories. In: Fedriani, C. \& A. Sansò (Eds), Pragmatic Markers, Discourse Markers, and Modal Particles. New Perspectives. Amsterdam, Benjamins, pp. 289-304.

Molinelli, Piera, Forthc. Sociocultural and linguistic constraints in address choice from Latin to Italian. In Beeching, K., Ghezzi, C. \& Molinelli, P. (Eds.), Positioning the self and others: Linguistic Perspectives. Amsterdam, Benjamins.

Murphy, James, 2015. How politicians use 'I'm sorry' to position themselves as not being sorry. Paper at the $14^{\text {th }}$ IPrA Conference, Antwerp.

Paternoster, Annick, Saltamacchia, Francesca, 2017, (Im)politeness Formulae and (Im)politeness Rules: Metadiscourse and Conventionalisation in 19th Century Italian Conduct Books. In: Pandolfi, E. M., J. Miecznikowski, S. Christopher \& A. Kamber (Eds.), Studies on Language Norms in Context. Frankfurt am Main, Peter Lang, pp. $263-301$.

Renzi, Lorenzo, 2010. Frasi iussive. In: Salvi, G. \& L. Renzi (Eds), Grammatica dell'italiano antico. Bologna, Il Mulino, II, pp. 1199-1210.

Scaglia, Claudia, 2003. Deissi e cortesia in italiano. Linguistica e filologia 16, 109145.

Traugott, E.C., Dasher, R.B., 2002. Regularity in Semantic Change. Cambridge, UP.

Thaler, Verena, 2014. Negative evaluation and face work in French and Italian online comments. In: Bedijs, K., G. Held \& C. Maaß (Eds.), Face Work and Social Media. Münster, LIT-Verlag, pp. 277-296.

Watts, Richard, 1992. Linguistic politeness and politic verbal behaviour: reconsidering claims for universality. In: Watts, R., S. Ide

K. Ehlich (Eds.), Politeness in Language: Studies in its History, Theory and Practice. Berlin, de Gruyter, pp. 43-69.

Wichmann, Anna, 2005. Please - from courtesy to appeal: The role of intonation in the expression of attitudinal meaning. English Language and Linguistics 9, 229-253. 
